\title{
PENGARUH WAKTU KONTAK AIR PAYAU DALAM SARINGAN PASIR DAN ARANG KAYU TERHADAP PENURUNAN JUMLAH BAKTERI COLI-FORM, KEKERUHAN DAN SALINITAS UNTUK KEBUTUHAN AIR MINUM
}

\author{
TH.Teddy Bambang, Suprapto, Mardan Ginting
}

\begin{abstract}
Abstrak
Air payau rasanya agak asin dan tidak segar umumnya keruh, tercemar oleh kotoran (tinja manusia) banyak mengandung bakteri patogen yang dapat menyebabkan penyakit dysentri, kholera, typhoid fever, infectius hepatitis, polio dan lain-lain jika digunakan langsung untuk air minum tanpa terlebih dahulu di masak.Untuk mengatasi masalah air payau yang keruh, mengandung bakteri patogen (E.coli) dan kadar garam (salinitas) yang jumlahnya berlebihan, maka dapat dilakukan salah satunya dengan menggunakan saringan pasir dan arang aktif. Penelitian ini bersifat eksperimental semu, dengan rancangan yang digunakan ialah PretestPostest Control Group design. Tujuan penelitian ini untuk mengetahui pengaruh waktu kontak air payau dalam saringan pasir dan arang kayu terhadap penurunan jumlah bakteri Coli-form , kekeruhan dan salinitas untuk kebutuhan air minum.Sampel yang digunakan adalah air payau dari Pulau Sicanang Belawan, media Saringan pasir dan arang kayu dengan ketinggian $70 \mathrm{~cm}$ waktu kontak 1 jam, 2 jam dan 3 jam. Pemeriksaan bakteri Coli-form pada sampel menggunakan pemeriksaan dengan tabung ganda, kekeruhan dengan Turbidity meter dan Salinitas menggunakan Refraktometer. Tempat penelitian dilakukan di ruang laboratorium terpadu Direktorat Poltekkes Kemenkes Medan dengan 3 (tiga) kali pengulangan.Analisa data dilakukan dari tahapan univariat, bivariat. Uji yang dipakai menggunakan t-test dan Anova dengan derajat kepercayaan 95\% $(\alpha=0,05)$.Hasil penelitian diperoleh bahwa saringan pasir dan arang kayau dapat menurunkan MPN Coli-form, kekeruhan dan salinitas dengan waktu kontak 3 jam sebesar 95,8\%, 85,6\%, 85,7\%, ada pengaruh waktu kontak 1 jam, 2 jam dan 3 jam air payau dalam saringan pasir dan arang kayu terhadap penurunan jumlah bakteri Coli-form dengan $\mathrm{p}=0,00(\mathrm{p}<\alpha=0,05)$, ada pengaruh waktu kontak air payau dalam saringan pasir dan arang kayu terhadap penurunan Coli fecal dengan $\mathrm{p}=0,00(\mathrm{p}<\alpha=0,05)$, ada pengaruh waktu kontak air payau dalam saringan pasir dan arang kayu terhadap penurunan kekeruhan dengan $\mathrm{p}=0,00(\mathrm{p}<\alpha=0,05)$ dan ada pengaruh waktu kontak air payau dalam saringan pasir dan arang kayu terhadap penurunan salinitas dengan $\mathrm{p}=0,01(\mathrm{p}<\alpha=0,05)$. Petugas Puskesmas dapat mensosialisasikan saringan pasir dan arang aktif dengan ketinggian $70 \mathrm{~cm}$ pada masyarakat yang menggunakan air payau untuk memperoleh air minum yang memenuhi syarat kesehatan.
\end{abstract}

Kata Kunci: Saringan pasir arang kayu, Coliform,Kekeruhan dan Salinitas

\section{Pendahuluan}

Air minum merupakan kebutuhan dasar manusia yang paling penting bagi kesehatan apabila memenuhi persyaratan fisika, mikrobiologis, kimiawi dan radioaktif yang dimuat dalam parameter wajib dan parameter tambahan.Kelangsungan hidup dan kualitas hidup manusia agar dapat terjamin harus menjaga kelestarian sumberdaya alam, khususnya sumber daya air.Namun tidak semua daerah mempunyai sumberdaya air yang baik (Permenkes RI Nomor :492/Menkes/Per/V/2010).Kebutuhan manusia akan air sangat kompleks antara lain untuk minum, masak, mandi,mencuci dan sebagainya. Air juga merupakan bagian dari lingkungan fisik yang sangat esensiel tidak hanya dalam proses-proses hidup tetapi juga untuk proses lain seperti untuk industri, pertanian, pemadam kebakaran, dan lain-lain ( Suparman,2006).
Wilayah pesisir pantai di Sumatera Utara seperti daerah Percut Sei Tuan, Pulau Sicanang,Pantai Labu, Pantai Cermin dan lainnya merupakan daerahdaerah yang sangat krisis akan sumber air tawar, sehingga timbul masalah pemenuhan kebutuhan air minum karena mereka memanfaatkan sumber air yang tersedia seperti air payau yang dapat menimbulkan gangguan kesehatan. Air payau yang terdapat di daerah tersebut umumnya keruh, agak asin dan tercemar kotoran, dimana dari segi kualitas belum memenuhi syarat kesehatan.Air yang tidak memenuhi syarat kesehatan dapat menimbulkan berbagai gangguan kesehatan bagi masyarakat penggunanya. Berbagai gangguan kesehatan yang ditimbulkan dari air yang tidak memenuhi syarat kesehatan antara lain penyakit dysentery,thypus dan paratyphus, kholera, hepatitis- A dan poliomielitis ( Said Nusa Idaman, 1999). 
Pemanfaatan air untuk keperluan rumah tangga harus memenuhi persyaratan, baik dari segi kuantitas maupun dari segi kualitas. Persyaratan dari segi kuantitas adalah air tersebut harus mempunyai jumlah yang cukup untuk digunakan baik sebagai air minum, air mencuci dan keperluan rumah tangga lainnya. Persyaratan dari segi kualitas, air harus memenuhi persyaratan fisik, kimia, mikrobiologi dan radioaktif. Parameter fisik air minum menurut Permenkes RI No.492/Menkes/SK/VI/2010 tentang persyaratan kualitas air minum adalah tidak berbau,tidak berasa, kekeruhan : 5 NTU. Parameter mikrobiologi adalah untuk E.coli dan Total Bakteri Coli-form adalah: 0 (Nihil) /100 ml sampel air.

Air payau mengandung beberapa jenis zat yang terlarut seperti garam-garam natrium khlorida, magnesium, kalsium, kalium dan sebagainya. Jumlah rata-ratanya berkisar antara 3,8 gr/l - 4,5 gr/l. Air payau jika digunakan untuk air minum rasanya agak asin dan tidak segar. Garam ( $\mathrm{NaCl}$ ) dibutuhkan tubuh dalam membantu perkembangan kecerdasan atau kepandaian pada anak, juga selain itu berfungsi untuk membentuk zat tiroksin yang terbentuk dalam kelenjar tiroid. Sekalipun garam dibutuhkan oleh tubuh tetapi dalam dosis besar dapat meningkatkan tekanan darah yang merupakan sumber penyakit seperti diabetes, stroke dan jantung. Air payau yang tercemar oleh kotoran ( tinja manusia ) banyak mengandung bakteri pathogen yang dapat menyebabkan penyakit dysenteri, kholera, typhoid fever, infectius hepatitis, polio dan lain-lain jika digunakan langsung untuk air minum tanpa terlebih dahulu di masak (Depkes RI, 1991).Untuk mengatasi masalah air payau yang mengandung kadar garam yang jumlah berlebihan dan mengandung bakteri pathogen (E.coli), maka dapat dilakukan salah satunya dengan pengolahan air secara fisika dengan menggunakan media saringan pasir dan arang kayu (BPPT, 1999).Penyaringan (filtrasi) adalah proses melewatkan air melalui media untuk menghilangkan zat-zat yang tersuspensi (Kusnaedi,1998).

Arang kayu dapat dipergunakan sebagai absorben cocok untuk pengolahan air olahan yang mengandung fenol dan bahan yang memiliki berat molekul tinggi. Arang kayu yang digunakan biasanya terbuat dari arang tempurung kelapa atau arang kayu sebagai media filtrasi (Kusnaedi,2006). Berdasarkan observasi peneliti di desa Pulau Sicanang Belawan merupakan desa yang berdekatan dengan kawasan pantai, air payau digunakan masyarakat sebagai sumber air bersih dengan cara pengambilan langsung ke daerah aliran sungai yang memiliki karakteristik salinitas 3,5 gr/l melewati batas yang telah ditetapkan Permenkes RI Nomor : 416/ Menkes/SK/XI/1990. Hal ini menunjukkan bahwa salinitas air di desa Pulau Sicanang tidak memenuhi syarat kesehatan untuk digunakan sebagai air bersih.

\section{Perumusan Masalah}

Bagaimana pengaruh waktu kontak air payau dalam media saringan pasir dan arang kayu terhadap penurunan jumlah bakteri Coli form, penurunan kekeruhan dan salinitas untuk kebutuhan air minum?

\section{Tujuan Penelitian \\ 1.Tujuan Umum}

Untuk mengetahui pengaruh waktu kontak air payau dalam media saringan pasir dan arang kayu terhadap penurunan jumlah bakteri Coli form, Colifecal, kekeruhan dan salinitas untuk kebutuhan air bersih.

\section{Tujuan Khusus}

1.Untuk menganalisis pengaruh waktu kontak air payau selama 1 jam, 2 jam dan 3 jam dalam media saringan pasir dan arang kayu terhadap penurunan MPN Coli form.

2.Untuk menganalisis pengaruh waktu kontak air payau selama 1 jam, 2 jam dan 3 jam dalam media saringan pasir dan arang kayu terhadap penurunan kekeruhan dan salinitas.

3.Untuk mengetahui perbedaan pengaruh waktu kontak air payau selama 1 jam, 2 jam dan 3 jam dalam media saringan pasir dan arang kayu terhadap MPN Coli form.

4.Untuk mengetahui perbedaan pengaruh waktu kontak air payau selama 1 jam, 2 jam dan 3 jam dalam media saringan pasir dan arang kayu terhadap penurunan kekeruhan dan salinitas.

\section{Hipotesa}

1. Ada pengaruh waktu kontak air payau selama 1 jam, 2 jam dan 3 jam dalam media saringan pasir dan arang kayu terhadap penurunan MPN Coli-form.

2. Ada pengaruh waktu kontak air payau selama 1 jam, 2 jam dan 3 jam dalam

media saringan pasir dan arang kayu terhadap penurunan kekeruhan dan salinitas.

\section{Manfaat penelitian}

1.Masyarakat di daerah pantai dapat memperoleh air bersih yang memenuhi syarat khususnya yang memanfaatkan air payau untuk kebutuhan seharihari.

2. Petugas Dinas Kesehatan Kota/ Kabupaten dan Puskesmas dapat mensosialisasikan media saringan pasir dan arang kayu kepada masyarakat untuk mengatasi masalah air payau untuk kebutuhan air minum.

\section{Metodologi Penelitian \\ 1.Tempat dan waktu penelitian}

Tempat penelitian ini dilakukan di Laboratorium terpadu Direktorat Poltekkes Kemenkes Medan Jalan Jamin Ginting Km 13,5 Kelurahan Lau Cih Kecamatan Medan Tuntungan Medan. 
Waktu penelitian dilaksanakan mulai bulan Juni September 2013.

\section{Desain dan metodologi penelitian}

1. Jenis penelitian ini bersifat eksperimen semu (quasi-experimental) yaitu untuk mengetahui pengaruh waktu kontak air payau dalam saringan pasir dan arang kayu terhadap jumlah bakteri Coli form dan penurunan kekeruhan dan salinitas.

Desain penelitian menggunakan metoda pre-test dan post-test kontrol design. Replikasi yang dilaksanakan sebanyak 3 (tiga) kali.

Desain yang akan dilakukan seperti dibawah ini :

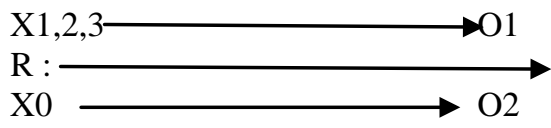

Keterangan :

X1,2,3 : Kelompok perlakuan.

$\mathrm{R} \quad$ : Replikasi.

Xo : Kelompok Kontrol (menggunakan kerikil Ø 1-2 cm)

O1 : Pengamatan jumlah Coli form, Coli fecal, penurunan kekeruhan dan salinitas air payau sesudah melalui saringan pasir dan arang kayu selama 1 jam, 2 jam dan 3 jam (kelompok perlakuan).

O2 :Pengamatan jumlah Coliform, penurunan kekeruhan dan salinitas air payau setelah melalui saringan kerikil selama 1 jam, 2 jam dan 3 jam (kelompok kontrol).

\section{Objek penelitian}

Objek penelitian ini adalah :
a. Air payau : diambil dari daerah Pulau Sicanang Belawan.
b. Pasir : digunakan pasir sungai dari Binjai.
c. Kerikil : diperoleh dari sungai Tuntungan.
d. Arang kayu : dipakai arang kayu bakau.

\section{Pengumpulan data}

Data primer diperoleh dengan cara memeriksakan air payau sebelum dan sesudah penyaringan saringan pasir dan arang kayu untuk bakteri Coli form, mengukur kekeruhan dan salinitas (kadar garam).

\section{Tehnik analisis data}

Analisis data dilakukan dari tahapan univariat, bivariat. Uji yang dipakai untuk hipotesa pada analisa bivariat bertujuan untuk menguji pengaruh waktu kontak terhadap jumlah Coli form, Coli-fecal, penurunan kekeruhan dan salinitas dengan menggunakan uji t-test dependent dan untuk melihat perbedaan jumlah Coliform, penurunan kekeruhan dan salinitas dilakukan uji Anova (Analisis of variance). Untuk melihat perbedaaan dari masing-masing variabel dilanjutkan dengan menggunakan uji “Tuckey-test”. Analisis data penelitian dengan menggunakan bantuan komputerisasi.

\section{Bahan dan Prosedur Kerja}

a. Bahan :

1. Air payau

2. Pasir sungai ukuran diameter $0,25-0,50 \mathrm{~mm}$.

3. Kerikil berdiameter $2 \mathrm{~cm}$.

4. Arang kayu bakau berdiameter $2 \mathrm{~cm}$.

5. Tabung paralon diameter $20 \mathrm{~cm}$ setinggi 100 $\mathrm{cm}$.

6. Pipa paralon $1 / 2$ inchi secukupnya.

7. Stock kran $1 / 2$ inci

8. Kran $1 / 2$ inchi.

9. Sok $1 / 2$ inchi

10.Lem paralon/ pipa.

11.Selotip

12.Ijuk.

b. Alat :

1. Ayakan pasir ukur 0,25 - 0,50 mm.

2. Ayakan kawat ukuran $2 \mathrm{~cm}$.

3. X-Turbidity meter.

4. Refraktometer.

c. Prosedur kerja :

1. Persiapkan media saringan pasir

a). Ambil pasir kali berdiameter 0,25-0,50 mm (volume 22 liter) tinggi $70 \mathrm{~cm}$ dan kerikil diameter 1 - $2 \mathrm{~cm}$ ( 3 liter ) tinggi $10 \mathrm{~cm}$.

b).Kemudian cuci pasir kali dan kerikil hingga bersih (tidak keruh lagi air cucian).

c).Ambil arang kayu bakau diameter $2 \mathrm{~cm}$ ( volume 22 liter) tinggi $70 \mathrm{~cm}$, kemudian dicuci sampai bersih.

2. Pembuatan media saringan pasir

a. Ambil tabung pipa paralon berdiameter $20 \mathrm{~cm}$ tinggi $100 \mathrm{~cm}$.

b. Pasang dop diameter $20 \mathrm{~cm}$ dengan menggunakan lem paralon di bagian bawah tabung pipa paralon.

c. Lubangi dinding tabung paralon bagian bawah dengan bor listrik diameter $1 / 2$ inchi dengan jarak 2,5 cm untuk tempat stok kran.

d. Pasang stok kran $1 / 2$ inchi pada dinding tabung paralon yang telah dilubangi tadi.

e. Letakkan kerikil yang telah bersih dibagian dasar tabung setinggi $10 \mathrm{~cm}$, masukkan ijuk yang bersih setebal $5 \mathrm{~cm}$ diatasnya.

f. Masukkan pasir kali yang telah dicuci diatas lapisan ijuk ke dalam tabung pipa paralon setinggi $70 \mathrm{~cm}$.

3. Pembuatan Saringan arang kayu :

a. Ambil tabung pipa paralon berdiameter $20 \mathrm{~cm}$ tinggi $100 \mathrm{~cm}$.

b. Pasang dop diameter $20 \mathrm{~cm}$ dengan menggunakan lem paralon di bagian bawah tabung pipa paralon.

c. Lubangi dinding tabung paralon bagian sisi kanan atas dengan jarak $10 \mathrm{~cm}$ untuk tempat stop kran dan sisi kiri bawah dengan bor listrik 
diameter $1 / 2$ inchi jarak 2,5 $\mathrm{cm}$ dari bawah tabung pipa paralon.

d. Pasang stock kran $1 / 2$ inchi pada dinding tabung paralon pada bagian atas dan stock kran $1 / 2$ inchi pada bagian bawah yang telah dilubangi tadi.

e. Ambil slang plastik $3 / 4$ inchi sepanjang \pm 80 $\mathrm{cm}$, hubungkan slang dari tabung saringan pasir dengan tabung saringan arang kayu pada bagian sisi bawah yang telah dipasang stock kran tadi.

f. Pasang stop kran $1 / 2$ inchi pada sisi kanan pipa paralon diameter $20 \mathrm{~cm}$.

g. Isi tabung pipa paralon dengan arang kayu bakau berdiameter 1-2 cm yang telah bersih setinggi $70 \mathrm{~cm}$ dari dasar tabung.

4. Pelaksanaan penyaringan air payau dengan saringan pasir dan arang kayu setinggi $70 \mathrm{~cm}$.

a. Sebelum dilakukan penyaringan media saringan pasir dan arang kayu disterilisasi dengan air mendidih sebanyak 3 kali.

b.Lakukan pemeriksaan awal Coli form, Coli-fecal, kekeruhan dan salinitas air payau sebelum penyaringan dilakukan ( pre-test ).

c.Tutup semua stop kran pada saringan pasir dan arang kayu,

alirkan air payau sebanyak 5 liter ke dalam tabung saringan pasir dan arang

kayu dengan kecepatan aliran 5-10 m/ jam.

d. Biarkan selama 1 jam ( 60 menit ).

e. Setelah 60 menit, buka stop kran saringan dan ambil air hasil penyaringan dengan menggunakan botol sampel steril.

f. Lakukan pemeriksaan Coli form, Coli-fecal, kekeruhan dan salinitas air payau hasil penyaringan ( post-test ).

g. Lakukan yang sama untuk waktu kontak dalam saringan pasir dan arang kayu selama 2 jam (120 menit) dan 3 jam (180 menit).

h. Lakukan dengan replikasi 3 (tiga) kali dari masing-masing waktu kontak.

\section{Pelaksanaan penyaringan air payau pada Kontrol}

a. Sebelum dilakukan penyaringan media saringan kerikil disterilisasi dengan air mendidih sebanyak 3 kali.

b. Lakukan pemeriksaan awal Coli form,Colifecal, kekeruhan dan salinitas air payau sebelumnya ( pre-test ).

c. Tutup stop kran pada tabung paralon yang berisi kerikil Ø 1-2 cm

d. Alirkan air pada payau sebanyak 5 liter kedalam media tabung pipa paralon yang berisi kerikil Ø 1-2 cm dengan kecepatan 5-10 $\mathrm{m} / \mathrm{jam}$.

e. Biarkan air payau selama 60 menit didalam tabung paralon yang berisi kerikil $\varnothing 1-2 \mathrm{~cm}$ setinggi $70 \mathrm{~cm}$. f. Setelah air payau 60 menit dalam tabung, buka stop kran ambil air dari hasil penyaringan dengan

g. Lakukan pemeriksaan Coli form, Coli-fecal, kekeruhan dan salinitas pada sampel air payau.

h. Lakukan hal yang sama untuk waktu kontak 2 jam dan 3 jam dalam tabung paralon berisi kerikil Ø 1 - $2 \mathrm{~cm}$ ( post-test ).

i. Lakukan dengan replikasi 3 (tiga) kali dari masing-masing waktu kontak.

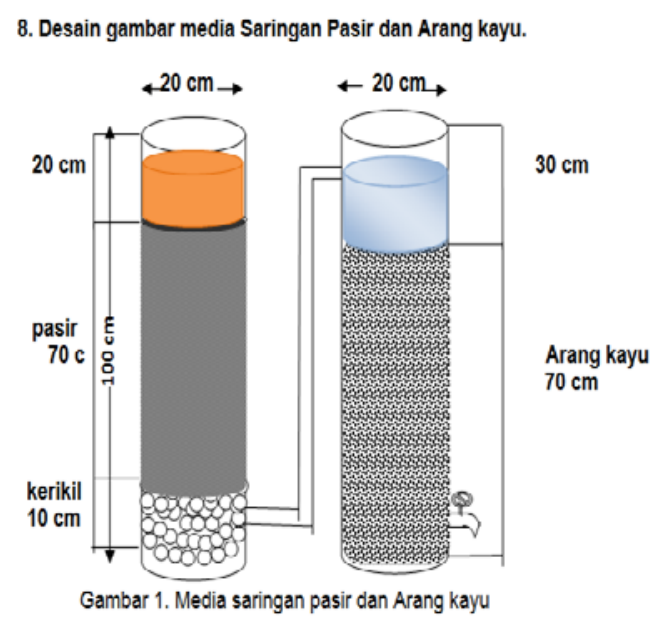

\section{Hasil Penelitian}

Berdasarkan hasil pemeriksaan di Laboratorium terpadu Poltekkes Kemenkes Medan sebelum dan setelah penyaringan didapatkan sebagai berikut :

\section{Analisis Univariat.}

\section{a. Bakteri Coli form.}

Hasil pemeriksaan bakteriologis sebelum dan sesudah penyaringan dalam waktu 1 jam, 2 jam dan 3 jam dapat dilihat padaTabel 4.1

Distribusi Frekuensi Penurunan MPN Coli form pada air payau sebelum dan sesudah melalui saringan pasir dan arang kayu waktu kontak 1 jam, 2 jam dan 3 jam

\begin{tabular}{|c|c|c|c|c|c|c|c|c|}
\hline \multirow[t]{2}{*}{ No. } & \multirow{2}{*}{$\begin{array}{l}\text { Jumlah bakteri } \\
\text { Coliform sebelum } \\
\text { melalui saringan } \\
\text { Pasir dan arang kayu } \\
\text { (MPN) }\end{array}$} & \multirow{2}{*}{$\begin{array}{l}\text { Kontrol } \\
\text { (MPN) }\end{array}$} & \multicolumn{6}{|c|}{$\begin{array}{l}\text { Penurunan MPN bakteri Coli-form sesudah } \\
\text { melalui saringan pasir dan arang kayu }\end{array}$} \\
\hline & & & $1 \mathrm{jam}$ & $\%$ & $2 \mathrm{jam}$ & $\%$ & jam & $\%$ \\
\hline 1 & 265 & 265 & 84 & 68,3 & 21 & 92,1 & 9 & 96,6 \\
\hline 2 & 265 & 265 & 12 & 95,5 & 12 & 95,5 & 2 & 99,2 \\
\hline 3 & 265 & 265 & 83 & 68,7 & 22 & 91,7 & 22 & 91,7 \\
\hline $\begin{array}{l}\text { Rata } \\
\text {-rata }\end{array}$ & 265 & 265 & 57 & 77,5 & 18,3 & 91,1 & 11 & 95,8 \\
\hline
\end{tabular}

Dari tabel 4.1 diatas terlihat bahwa rata-rata jumlah bakteri coli-form sebelum melalui saringan pasir dan arang kayu dan kontrol sebanyak Most Probable Number (MPN) atau perkiraan terdekat jumlah bakteri Coli-form $=265$, penurunan rata-rata MPN bakteri Coliform sesudah melalui saringan pasir dan arang kayu waktu kontak 1 jam sebanyak 57 (77,5 \%), waktu kontak 2 jam sebanyak 18,3 (91,1 \%) dan waktu kontak 3 jam sebanyak $11(95,8 \%)$. 


\section{b. Kekeruhan.}

Hasil pemeriksaan kekeruhan sebelum dan sesudah penyaringan dalam waktu 1 jam, 2 jam dan 3 jam dapat dilihat pada tabel 4.2 di bawah ini.

TTabel 4.2

Distribusi Frekuensi Penurunan Kekeruhan pada air payau sebelum dan sesudah melalui saringan pasir dan arang waktu waktukontak 1 jam, 2 jam dan 3 jam

\begin{tabular}{|c|c|c|c|c|c|c|c|c|}
\hline \multirow[b]{2}{*}{ №. } & \multirow{2}{*}{$\begin{array}{l}\text { Kekeruhanair } \\
\text { payau sebelum } \\
\text { melalui } \\
\text { Saringan Pasir } \\
\text { dan Arang kayu } \\
\text { ( NTU) } \\
\end{array}$} & \multirow{2}{*}{$\begin{array}{l}\text { Kontrol } \\
\text { (NTU) }\end{array}$} & \multicolumn{6}{|c|}{$\begin{array}{l}\text { Penurunan Kekeruhan sesudah melalui } \\
\text { saringan pasir dan arang kayu ( NTU ) }\end{array}$} \\
\hline & & & $1 \mathrm{jam}$ & $\%$ & $2 \mathrm{jam}$ & $\%$ & $3 \mathrm{jam}$ & $\%$ \\
\hline 1 & 36,025 & 36,025 & 4,75 & 86,8 & 4,22 & 88,3 & 5,08 & 85,9 \\
\hline 2 & 36,025 & 36,025 & 4,10 & 88,5 & 4,47 & 87,8 & 5,25 & 85,4 \\
\hline 3 & 36,025 & 36,025 & 4,39 & 87,8 & 4,18 & 88,6 & 5,27 & 85,4 \\
\hline $\begin{array}{l}\text { Rata } \\
\text {-rata }\end{array}$ & 36,025 & 36,025 & 4,41 & 87,7 & 4,29 & 88,3 & 5,20 & 85,6 \\
\hline
\end{tabular}

Berdasarkan tabel 4.2 terlihat bahwa konsentrasi kekeruhan air payau sebelum penyaringan dan Kontrol rata-rata 36,025 NTU,setelah melalui saringan pasir dan arang kayu selalu waktu kontak 1 jam rata-rata menurun menjadi 4,41 NTU (87,7\%), waktu kontak setelah 2 jam rata-rata menurun menjadi $4,29 N T U(88,3 \%)$ dan setelah 3 jam rata-rata menjadi 5,20 NTU (85,6\%).

\section{c. Salinitas.}

Penurunan salinitas sebelum dan sesudah penyaringan dalam waktu kontak 1 jam, 2 jam dan 3 jam dapat dilihat pada tabel 4.3 di bawah ini.

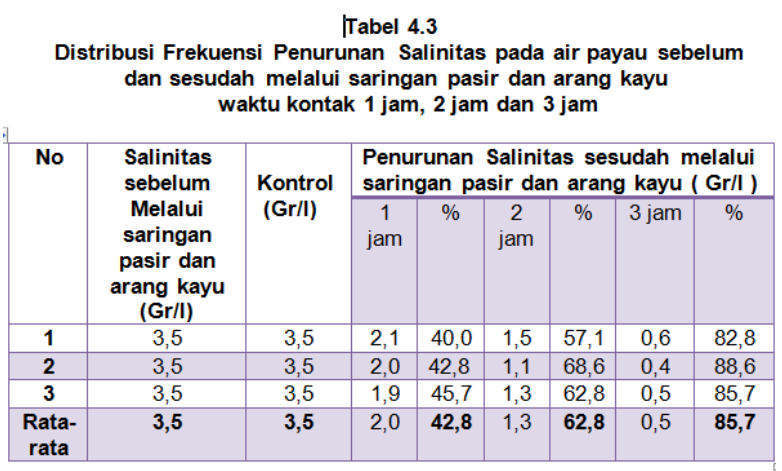

Berdasarkan tabel 4.3 diatas bahwa salinitas air payau sebelum penyaringan dan kontrol rata-rata 3,5 $\mathrm{gr} / \mathrm{l}$, setelah melalui saringan pasir dan arang waktu kontak 1 jam hasil rata-rata : 2,0 gr/l (42,8\%), 2 jam waktu kontak hasil rata-rata : $1,3 \mathrm{gr} / \mathrm{l}$ dan waktu kontak 3 jam hasil rata-rata : 0,5 gr/l (85,7\%).

\section{Analisis Bivariat}

\section{a. Pengaruh waktu kontak air payau dengan} penurunan Bakteri Coli-form.

Berdasarkan hasil uji t-test dependen pada waktu kontak air payau dalam saringan pasir dan arang kayu sebelum dan sesudah perlakuan dapat dilihat pada tabel dibawah ini.

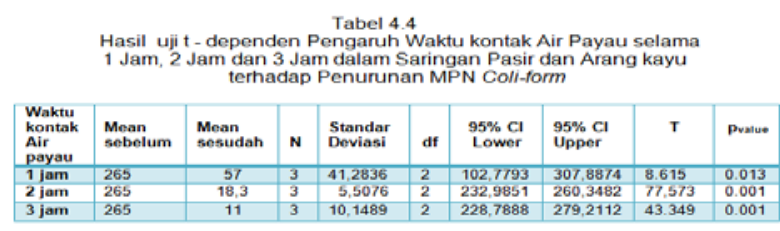

Dari tabel diatas dapat dilihat sesudah perlakuan dengan waktu kontak 1 jam air payau dalam saringan pasir dan arang kayu mempunyai rata-rata MPN Coli-form : 57 dengan 95\%-CI ( 102,7793 $307,8874)$ nilai $\mathrm{p}_{\text {value }}: 0,013(\mathrm{p}<\alpha=0,05)$. Pada waktu kontak selama 2 jam mempunyai rata-rata MPN Coliform :18,3 dengan 95\% - CI ( 232,9851 - 260,3482) nilai $\mathrm{p}_{\text {value }}: 0,001(\mathrm{p}<\alpha=0,05)$. Pada waktu kontak selama 3 jam mempunyai rata-rata MPN Coli-form : 11 dengan 95\% - CI ( 228,7888 - 279,2112 ) nilai p palue : $0,001(\mathrm{p}<\alpha=0,05)$.

\section{b. Pengaruh waktu kontak air payau dengan penurunan Kekeruhan.}

Berdasarkan hasil uji t-test dependen pada waktu kontak air payau dalam saringan pasir dan arang kayu sebelum dan sesudah perlakuan dapat dilihat pada tabel 4.5 dibawah ini.

Tabel 4.5

Hasil uij t - dependen Pengaruh Waktu Kontak Air Payau selama 1 Jam, 2 Jam, 3 Jam dalam Saringan Pasir dan Arang Kayu terhadap Penurunan Kekeruhan

\begin{tabular}{|l|l|l|l|l|c|c|c|c|c|}
\hline $\begin{array}{l}\text { Waktu } \\
\text { kontak } \\
\text { Air payau }\end{array}$ & $\begin{array}{l}\text { Mean } \\
\text { sebelum }\end{array}$ & $\begin{array}{l}\text { Mean } \\
\text { susudah }\end{array}$ & N & $\begin{array}{l}\text { Standar } \\
\text { Deviasi }\end{array}$ & $\begin{array}{c}\text { 95\% } \\
\text { Lower }\end{array}$ & $\begin{array}{c}95 \% \mathrm{Cl} \\
\text { Upper }\end{array}$ & df & T & p valus \\
\hline 1 jam & 36,025 & 4,4 & 3 & 0,3256 & 30,8028 & 32,4208 & 2 & 168,146 & 0.001 \\
\hline 2 jam & 36.025 & 4,2 & 3 & 0,1572 & 31,3446 & 32,1254 & 2 & 349,744 & 0.001 \\
\hline 3 jam & 36.025 & 5,2 & 3 & 0,1044 & 30,5656 & 31,0844 & 2 & 511,388 & 0.001 \\
\hline
\end{tabular}

Dari tabel 4.7 diatas dapat dilihat sesudah perlakuan dengan waktu kontak 1 jam air payau dalam saringan pasir dan arang kayu mempunyai rata-rata Kekeruhan $=4,4$ NTU dengan $\mathrm{p}_{\text {value }}: 0,001(\mathrm{p}<\alpha=0,05)$. Pada waktu kontak selama 2 jam mempunyai rata-rata kekeruhan $=4,2$ NTU dengan $\mathrm{p}_{\text {value }}: 0,001(\mathrm{p}<\alpha=0,05)$. Pada waktu kontak selama 3 jam mempunyai rata-rata kekeruhan $=5,2$ dengan $\mathrm{p}_{\text {value }}: 0,001(\mathrm{p}<\alpha=0,05)$.

\section{c. Pengaruh waktu kontak air payau dengan penurunan Salinitas.}

Berdasarkan hasil uji t-test dependen pada waktu kontak air payau dalam saringan pasir dan arang kayu sebelum dan sesudah perlakuan dapat dilihat pada tabel 4.6 dibawah ini.

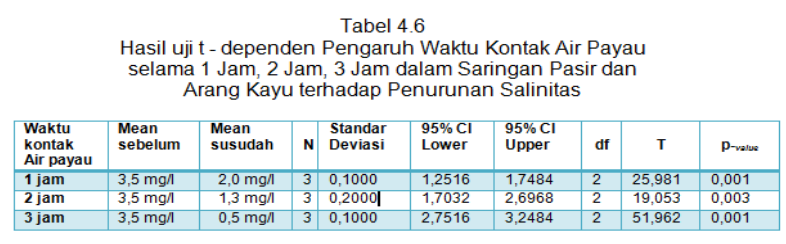

Dari tabel 4.6 diatas dapat dilihat sesudah perlakuan dengan waktu kontak 1 jam air payau dalam saringan pasir dan arang kayu mempunyai rata-rata salinitas = $2,0 \mathrm{gr} / \mathrm{l}$ dengan $95 \%$ - CI $(1,2516-1,7484)$ nilai $\mathrm{p}_{\text {value }}=$ 
0,001 ( $\mathrm{p}<\alpha=0,05)$. Pada waktu kontak selama 2 jam mempunyai rata-rata salinitas $=1,3 \mathrm{gr} / \mathrm{l}$ dengan $95 \%$ CI $(1,7032-2,6968)$ nilai $\mathrm{p}_{\text {value }}=0,003(\mathrm{p}<\alpha=$ 0,05). Pada waktu kontak selama 3 jam mempunyai rata-rata salinitas $=0,5 \mathrm{gr} / \mathrm{l}$ dengan dengan $95 \%$ - CI $(2,7516-3,2484)$ nilai $\mathrm{p}_{\text {value }}=0,001$.

\section{Uii perbedaan pengaruh waktu kontak}

\begin{tabular}{|c|c|c|c|c|c|}
\hline & Sum of Squares & Df & Mean Square & $F$ & Sig. \\
\hline $\begin{array}{l}\text { Between } \\
\text { Groups }\end{array}$ & 128739,667 & 3 & 42913,222 & 93,408 & 0,001 \\
\hline Within Groups & 3675,333 & 8 & 459,417 & & \\
\hline Total & 132415,000 & 11 & & & \\
\hline
\end{tabular}

F-hitung pada uji Anova diatas adalah 93,408 dengan probabilitas yaitu 0,001 karena $\alpha=0,05$, maka ada perbedaan pengaruh waktu kontak air payau pada waktu sebelum dan sesudah perlakuan selama 1 jam, 2 jam dan 3 jam terhadap penurunan MPN Coli-form. Untuk melihat uji beda, selanjutnya pada tabel 4.8 dapat dilihat lebih jelas seperti pada hasil sebagai berikut:

Tabel 4.8. Uji beda waktu kontak air payau terhadap Penurunan MPN Coli-form dalam Saringan pasir dan Arang kayu

\begin{tabular}{|c|c|c|c|c|c|c|}
\hline \multirow{2}{*}{$\begin{array}{l}\text { Waktu kontak } \\
\text { kontak } \\
\text { (I) }\end{array}$} & \multirow{2}{*}{$\begin{array}{l}\text { Waktu } \\
\text { (J) }\end{array}$} & \multirow{2}{*}{$\begin{array}{l}\text { Mean } \\
\text { Difference } \\
\text { (I-J) }\end{array}$} & \multirow[b]{2}{*}{$\begin{array}{l}\text { Std. } \\
\text { Error }\end{array}$} & \multirow[b]{2}{*}{ Sig. } & \multicolumn{2}{|c|}{ 95\% Confidence Interval } \\
\hline & & & & & Lower Bound & Upper Bound \\
\hline Pre-tes & $\begin{array}{l}1 \text { jam } \\
2 \text { jam } \\
3 \text { jam }\end{array}$ & $\begin{array}{l}205,33333^{*} \\
246,66667^{*} \\
254,00000^{*}\end{array}$ & $\begin{array}{l}17,50079 \\
17,50079 \\
17,50079\end{array}$ & $\begin{array}{l}0,000 \\
0,000 \\
0,000\end{array}$ & $\begin{array}{l}164,9764 \\
206,3098 \\
213,6431\end{array}$ & $\begin{array}{l}245,6902 \\
287,0236 \\
294,3569\end{array}$ \\
\hline 1 jam & $\begin{array}{l}\text { Pre test } \\
2 \text { jam } \\
3 \text { jam }\end{array}$ & $\begin{array}{l}-205,33333^{*} \\
41,33333^{*} \\
48,66667^{*}\end{array}$ & $\begin{array}{l}17,50079 \\
17,50079 \\
17,50079\end{array}$ & $\begin{array}{l}0,000 \\
0,046 \\
0,024\end{array}$ & $\begin{array}{l}-245,6902 \\
0,9764 \\
8,3098\end{array}$ & $\begin{array}{l}-164,9764 \\
81,6902 \\
89,0236\end{array}$ \\
\hline 2 jam & $\begin{array}{l}\text { Pre test } \\
1 \text { jam } \\
3 \text { jam }\end{array}$ & $\begin{array}{l}-246,66667^{*} \\
-41,33333^{*} \\
7,33333\end{array}$ & $\begin{array}{l}17,50079 \\
17,50079 \\
17,50079 \\
\end{array}$ & $\begin{array}{l}0,000 \\
0,046 \\
0,686 \\
\end{array}$ & $\begin{array}{l}-287,0236 \\
-81,6902 \\
-33,0236 \\
\end{array}$ & $\begin{array}{l}-206,3098 \\
-0,9764 \\
47,6902 \\
\end{array}$ \\
\hline 3 jam & $\begin{array}{l}\text { Pre test } \\
1 \text { jam } \\
2 \text { jam }\end{array}$ & $\begin{array}{l}-254,00000^{*} \\
-48,66667^{*} \\
-7,33333\end{array}$ & $\begin{array}{l}17,50079 \\
17,50079 \\
17,50079\end{array}$ & $\begin{array}{l}0,000 \\
0,024 \\
0,686\end{array}$ & $\begin{array}{l}-294,3569 \\
-89,0236 \\
-47,6902\end{array}$ & $\begin{array}{l}-213,6431 \\
-8,3098 \\
33,0236\end{array}$ \\
\hline
\end{tabular}

Melihat pada tabel 4.8 uji beda waktu kontak pada Pre-tes dengan perlakuan 1 jam memiliki beda nyata penurunan MPN Coli-form dengan nilai $\mathrm{p}_{\text {value }}=0,001<\alpha=$ 0,05, pada 95\%-CI (164,9764 - 245,6902), dengan perlakuan 2 jam memiliki beda nyata dengan nilai $\mathrm{p}_{\text {value }}=$ $0,001<\alpha=0,05$, pada 95\%-CI ( 206,3098 - 287,0236), serta dengan perlakuan 3 jam memiliki beda nyata dengan nilai $\mathrm{p}_{\text {value }}=0,001<\alpha=0,05$, pada $95 \%$-CI $(213,6431-$ 294,3569).

Perbedaan waktu kontak pada 1 jam dengan Pre-tes memiliki beda nyata dengan nilai $\mathrm{p}_{\text {value }}=0,001<\alpha=0,05$, pada 95\% - CI ( -245,6902 - (-164,9764), waktu kontak 1 jam dengan 2 jam memiliki beda nyata dengan nilai $\mathrm{p}_{\text {value }}$ $=0,046<\alpha=0,05$, pada $95 \%$ - CI $(0,9704-81,6902)$, waktu kontak 1 jam dengan 3 jam memiliki beda nyata dengan nilai $\mathrm{p}_{\text {value }}=0,024<\alpha=0,05$, pada $95 \%$ - CI $(8,3098$ - 89,0236).

Perbedaan waktu kontak pada 2 jam dengan Pretes memiliki beda nyata dengan nilai $\mathrm{p}_{\text {value }}=0,001<\alpha=$ 0,05, pada 95\% - CI $\quad(-287,0236-\quad(-206,3098)$, dengan waktu 1 jam memiliki beda nyata dengan nilai $\mathrm{p}_{\text {value }}=0,046<\alpha=0,05$, pada $95 \%$ - CI $\quad(-81,6902-$ $(-0,9764)$, serta dengan waktu 3 jam tidak memiliki beda nyata dengan nilai $\mathrm{p}_{\text {value }}=0,686>\alpha=0,05$, pada $95 \%$ - CI $(-33,0236-47,6902)$.

\section{b. Uji beda Penurunan Kekeruhan.}

Tabel 4.9. Penurunan Kekeruhan air payau pada perlakuanTerhadap masing-masing waktu kontak

\begin{tabular}{|l|l|l|l|l|l|}
\hline & $\begin{array}{l}\text { Sum of } \\
\text { Squares }\end{array}$ & $\begin{array}{l}\text { Mean } \\
\text { Square }\end{array}$ & F & Sig. \\
\hline $\begin{array}{l}\text { Between } \\
\text { Groups }\end{array}$ & 2219,009 & 3 & 739,670 & 20888,474 & 0,001 \\
$\begin{array}{l}\text { Within } \\
\text { Groups }\end{array}$ & 0,283 & 8 & 0,035 & & \\
Total & 2219,292 & 11 & & & \\
\hline
\end{tabular}

F-hitung pada uji Anova diatas adalah 20888,474 dengan probabilitas yaitu 0,001 karena $\alpha=0,05$, maka ada perbedaan pengaruh waktu kontak air payau pada waktu sebelum dan sesudah perlakuan 1 jam, 2 jam dan 3 jam terhadap penurunan kekeruhan.Untuk melihat uji beda, selanjutnya pada tabel 4.10 dapat dilihat lebih jelas seperti pada hasil sebagai berikut: 
Tabel 4.10. Uji beda waktu kontak air payau terhadap Penurunan Kekeruhan dalam Saringan pasir dan Arang kayu

\begin{tabular}{|c|c|c|c|c|c|c|}
\hline \multirow{2}{*}{$\begin{array}{l}\text { Waktu kontak } \\
\text { kontak } \\
\text { (I) }\end{array}$} & \multirow{2}{*}{$\begin{array}{l}\text { Waktu } \\
\text { (J) }\end{array}$} & \multirow{2}{*}{$\begin{array}{l}\text { Mean } \\
\text { Difference } \\
\text { (I-J) }\end{array}$} & \multirow[b]{2}{*}{$\begin{array}{l}\text { Std. } \\
\text { Error }\end{array}$} & \multirow[b]{2}{*}{ Sig. } & \multicolumn{2}{|c|}{ 95\% Confidence Interval } \\
\hline & & & & & Lower Bound & Upper Bound \\
\hline Pre-tes & $\begin{array}{l}1 \text { jam } \\
2 \text { jam } \\
3 \text { jam }\end{array}$ & $\begin{array}{l}31,6150 *^{*} \\
31,73833^{*} \\
30,82833^{*}\end{array}$ & $\begin{array}{l}0,15365 \\
0,15365 \\
0,15365\end{array}$ & $\begin{array}{l}\mathbf{0 , 0 0 0} \\
\mathbf{0 , 0 0 0} \\
\mathbf{0 , 0 0 0}\end{array}$ & $\begin{array}{l}31,2607 \\
31,3840 \\
30,4740\end{array}$ & $\begin{array}{l}31,9693 \\
32,0926 \\
31,1826\end{array}$ \\
\hline 1 jam & $\begin{array}{l}\text { Pre test } \\
2 \text { jam } \\
3 \text { jam }\end{array}$ & $\begin{array}{l}-31,61500^{*} \\
0,12333 \\
-0,78667^{*}\end{array}$ & $\begin{array}{l}0,15365 \\
0,15365 \\
0,15365 \\
\end{array}$ & $\begin{array}{l}0,000 \\
0,445 \\
0,001 \\
\end{array}$ & $\begin{array}{l}-31,9693 \\
-0,2310 \\
-1,1410 \\
\end{array}$ & $\begin{array}{l}-31,2607 \\
0,4776 \\
-0,4324 \\
\end{array}$ \\
\hline 2 jam & $\begin{array}{l}\text { Pre test } \\
1 \text { jam } \\
3 \text { jam }\end{array}$ & $\begin{array}{l}-31,73833^{*} \\
-0,12333 \\
-0,91000^{*}\end{array}$ & $\begin{array}{l}0,15365 \\
0,15365 \\
0,15365\end{array}$ & $\begin{array}{l}0,000 \\
0,445 \\
0,000\end{array}$ & $\begin{array}{l}-32,0926 \\
-0,4776 \\
-1,2643\end{array}$ & $\begin{array}{l}-31,3840 \\
0,2310 \\
-0,5557\end{array}$ \\
\hline 3 jam & $\begin{array}{l}\text { Pre test } \\
1 \text { jam } \\
2 \text { jam }\end{array}$ & $\begin{array}{l}-30,82833^{*} \\
0,78667^{*} \\
0,9100 *^{*}\end{array}$ & $\begin{array}{l}0,15365 \\
0,15365 \\
0,15365\end{array}$ & $\begin{array}{l}0,000 \\
0,001 \\
0,000\end{array}$ & $\begin{array}{l}-31,1826 \\
0,4324 \\
0,5557\end{array}$ & $\begin{array}{l}-30,4740 \\
1,1410 \\
1,2643\end{array}$ \\
\hline
\end{tabular}

Melihat pada tabel 4.10 perbedaan waktu kontak pada Pre-tes dengan 1 jam memiliki beda nyata penurunan Kekeruhan dengan nilai $\mathrm{p}_{\text {value }}=0,001<\alpha=0,05$, pada $95 \%$ CI ( 31,2607 - 31,9693), dengan perlakuan 2 jam memiliki beda nyata dengan nilai $\mathrm{p}_{\text {value }}=0,001<\alpha=0,05$, pada 95\%-CI ( 31,3840 - 32,0926), serta dengan perlakuan 3 jam memiliki beda nyata dengan nilai $p_{\text {value }}=0,001<\alpha=$ 0,05, pada 95\%-CI (30,4740 - 31,1826).

Perbedaan waktu kontak pada 1 jam dengan Pre-tes memiliki beda nyata dengan nilai $\mathrm{p}_{\text {value }}=0,001<$ $\alpha=0,05$, pada $95 \%$ - CI $\quad(-31,9693-(-31,2607)$, dengan perlakuan 2 jam tidak memiliki beda nyata dengan nilai $\mathrm{p}_{\text {value }}=0,445>\alpha=0,05$, pada $95 \%$ - CI ( $-0,2310$ - 0,4776), serta dengan perlakuan 3 jam memiliki beda nyata dengan nilai $\mathrm{p}_{\text {value }}=0,001<\alpha=$ 0,05 , pada $95 \%$ - CI $\quad(-1,1410-(-0,4324)$.
4.1.3.2. Uji beda Penurunan Salinitas

Tabel 4.11. Penurunan Salinitas air payau pada perlakuan Terhadap masing-masing waktu kontak

\begin{tabular}{|l|l|l|l|l|l|}
\hline & $\begin{array}{l}\text { Sum of } \\
\text { Squares }\end{array}$ & Df & $\begin{array}{l}\text { Mean } \\
\text { Square }\end{array}$ & F & Sig. \\
\hline $\begin{array}{l}\text { Between } \\
\text { Groups }\end{array}$ & 14,603 & 3 & 4,868 & 324,500 & 0,001 \\
$\begin{array}{l}\text { Within } \\
\text { Groups }\end{array}$ & 0,120 & 8 & 0,015 & & \\
Total & 14,722 & 11 & & & \\
\hline
\end{tabular}

F-hitung pada uji Anova diatas adalah 324,500 dengan probabilitas yaitu 0,001 karena $\alpha=0,05$, maka ada perbedaan pengaruh waktu kontak air payau pada waktu sebelum dan sesudah perlakuan selama 1 jam, 2 jam dan 3 jam terhadap penurunan Salinitas.Untuk melihat uji beda, selanjutnya pada tabel 4.12 dapat dilihat lebih jelas seperti pada hasil sebagai berikut:

Tabel 4.12. Uji beda masing-masing waktu kontak air payau terhadap penurunan Salinitas dalam Saringan pasir dan Arang kayu

\begin{tabular}{|c|c|c|c|c|c|c|}
\hline \multirow{2}{*}{$\begin{array}{l}\text { Waktu kontak } \\
\text { (I) }\end{array}$} & \multirow{2}{*}{$\begin{array}{c}\text { Waktu kontak } \\
\text { (J) }\end{array}$} & \multirow{2}{*}{$\begin{array}{l}\text { Mean } \\
\text { Difference } \\
\text { (I-J) }\end{array}$} & \multirow[b]{2}{*}{$\begin{array}{l}\text { Std. } \\
\text { Error }\end{array}$} & \multirow[b]{2}{*}{ Sig. } & \multicolumn{2}{|c|}{ 95\% Confidence Interval } \\
\hline & & & & & Lower Bound & Upper Bound \\
\hline Pre-tes & $\begin{array}{l}1 \text { jam } \\
2 \text { jam } \\
3 \text { jam }\end{array}$ & $\begin{array}{l}1,50000^{*} \\
2,20000^{*} \\
3,00000^{*}\end{array}$ & $\begin{array}{l}\mathbf{0 , 1 0 0 0 0} \\
\mathbf{0 , 1 0 0 0 0} \\
\mathbf{0 , 1 0 0 0 0} \\
\end{array}$ & $\begin{array}{l}0,000 \\
0,000 \\
0,000\end{array}$ & $\begin{array}{l}1,2694 \\
1,9694 \\
2,7694\end{array}$ & $\begin{array}{l}1,7306 \\
2,4306 \\
3,2306\end{array}$ \\
\hline 1 jam & $\begin{array}{l}\text { Pre test } \\
2 \text { jam } \\
3 \text { jam }\end{array}$ & $\begin{array}{l}-1,5000 *^{*} \\
0,7000 *^{*} \\
1,5000{ }^{*}\end{array}$ & $\begin{array}{l}\mathbf{0 , 1 0 0 0 0} \\
\mathbf{0 , 1 0 0 0 0} \\
\mathbf{0 , 1 0 0 0 0}\end{array}$ & $\begin{array}{l}0,000 \\
0,000 \\
0,000 \\
\end{array}$ & $\begin{array}{l}-1,7306 \\
0,4694 \\
1,2694\end{array}$ & $\begin{array}{l}-1,2694 \\
0,9306 \\
1,7306\end{array}$ \\
\hline 2 jam & $\begin{array}{l}\text { Pre test } \\
1 \text { jam } \\
3 \text { jam }\end{array}$ & $\begin{array}{c}-2,20000^{*} \\
-0,70000^{*} \\
0,80000^{*}\end{array}$ & $\begin{array}{l}0,10000 \\
0,10000 \\
0,10000\end{array}$ & $\begin{array}{l}0,000 \\
0,000 \\
0,000 \\
\end{array}$ & $\begin{array}{l}-2,4306 \\
-0,9306 \\
0,5694\end{array}$ & $\begin{array}{l}-1,9694 \\
-0,4694 \\
1,0306\end{array}$ \\
\hline 3 jam & $\begin{array}{l}\text { Pre test } \\
1 \text { jam } \\
2 \text { jam }\end{array}$ & $\begin{array}{l}-3,00000^{*} \\
1,50000^{*} \\
-0,80000^{*}\end{array}$ & $\begin{array}{l}0,10000 \\
0,10000 \\
0,10000\end{array}$ & $\begin{array}{l}\mathbf{0 , 0 0 0} \\
\mathbf{0 , 0 0 0} \\
\mathbf{0 , 0 0 0}\end{array}$ & $\begin{array}{l}-3,2306 \\
-1,7306 \\
-1,0306\end{array}$ & $\begin{array}{l}-2,7694 \\
-1,2694 \\
-0,5694\end{array}$ \\
\hline
\end{tabular}


Melihat pada tabel 4.12 perbedaan waktu kontak pada Pre-tes dengan 1 jam memiliki beda nyata penurunan Salinitas dengan nilai $\mathrm{p}_{\text {value }}=0,001<\alpha=0,05$, pada $95 \%$-CI ( $1,2694-1,7306)$, dengan waktu kontak 2 jam memiliki beda nyata dengan nilai $\mathrm{p}_{\text {value }}=0,001<\alpha=0,05$, pada 95\%-CI ( 1,9694 - 2,4306), serta dengan waktu kontak 3 jam memiliki beda nyata dengan nilai $\mathrm{p}_{\text {value }}=0,001<\alpha=$ 0,05, pada 95\%-CI (2,7694 - 3,2306).

Perbedaan waktu kontak pada 1 jam dengan Pre-tes memiliki beda nyata dengan nilai $\mathrm{p}_{\text {value }}=0,001<\alpha=0,05$, pada 95\% - CI ( -1,7306 - ( -1,2694), dengan waktu kontak 2 jam memiliki beda nyata dengan nilai $\mathrm{p}_{\text {value }}$ $=0,001<\alpha=0,05$, pada $95 \%$ - CI $\quad(0,4694-0,9306)$, serta dengan waktu kontak 3 jam memiliki beda nyata dengan nilai $\mathrm{p}_{\text {value }}=0,001<\alpha=0,05$, pada $95 \%$ - CI ( $1,2694-1,7306)$.

\section{Pembahasan}

\section{Penurunan bakteri Coli-form}

Pengamatan hasil analisis univariat terlihat bahwa penurunan jumlah bakteri Coli-form pada tabel 4.1, terlihat bahwa waktu kontak air payau 1 jam dalam saringan pasir dan arang kayu rata-rata penurunan MPN bakteri Coliform adalah 77,5 \%, pada waktu kontak 2 jam rata-rata penurunan MPN bakteri sampai 91,1 \%, sedangkan pada waktu kontak air payau selama 3 jam rata-rata mencapai penurunan 95,8 \%. Meningkatnya penurunan MPN bakteri Coli-form ini mulai dari waktu kontak 1 jam, 2 jam dan 3 jam; disebabkan tekanan air payau semakin lama semakin besar terhadap lapisan pasir dan arang kayu membuat butiran menjadi padat sehingga membuat semakin kecilnya porositas.

Secara Fisika, partikel-partikel yang ada dalam sumber air yang keruh atau kotor akan tertahan oleh lapisan pasir yang ada pada saringan. Secara biologi, pada saringan akan terbentuk sebuah lapisan bakteri. Bakteribakteri dari genus Pseudomonas dan Trichoderma akan tumbuh dan berkembang biak membentuk sebuah lapisan khusus. Pada saat proses filtrasi dengan debit air lambat (100-200 liter/jam/m2 luas permukaan saringan), patogen yang tertahan oleh saringan akan dimusnahkan oleh bakteri-bakteri tersebut (SatrioWibowo;http://aimyaya.com/id).

Disamping mekanis juga biologis pada lapisan pasir bagian atas terdapat lapisan lendir, yang berguna untuk menahan bakteri-bakteri. (Sanropie Djasio, dkk;1984). Bakteri Coli-form jika masih yang lolos dari saringan pasir akan diserap oleh saringan arang kayu. Hal ini menunjukkan bahwa saringan pasir dan arang kayu sangat berperan dan mampu menurunkan bakteri Coli-form dalam air payau. Hal ini sesuai dengan hasil penelitian BPPT tahun 2000 dengan saringan pasir dapat menurunkan bakteriologi E.coli sampai 95\%.

Hasil analisis bivariat pada tabel 4.5 terlihat bahwa waktu kontak air payau 1 jam, 2 jam dan 3 jam dalam saringan pasir dan arang kayu terhadap penurunan bakteri Coli-form menunjukkan ada pengaruh dengan probabilitas masing-masing $\mathrm{p}$-value $=0,013$, $\mathrm{p}$-value $=0,001$ dan $\mathrm{p}$ value $=0,001(\mathrm{p}<\alpha=0,05)$. Hal ini disebabkan lapisan pasir dan arang kayu dapat merapat penuh dan porositas lapisan pasir dan arang menahan air payau dan terbentuk lapisan lendir pada permukaan pasir sehingga air payau yang mengandung bakteri tersaring. Melihat waktu kontak air payau tersebut dalam saringan, menunjukkan adanya perubahan yang signifikan terhadap penurunan jumlah bakteri Coli-form dimana probabilitas $\mathrm{p}=0,001(\mathrm{p}<\alpha$ $=0,05$ ) ini berarti ada pengaruh waktu kontak air payau selama 1 jam, 2 jam dan 3 jam sangat signifikan terhadap penurunan bakteri Coli-form. Hal ini sesuai dengan hasil penelitian Herman,Hermawan, 2006 bahwa ada pengaruh saringan pasir lambat ketebalan $60 \mathrm{~cm}$ model IOS-SF terhadap penurunan total Coli-form ( $\mathrm{p}_{\text {value }}=0,001<\alpha=$ 0,05). Jadi dapat disimpulkan bahwa untuk menurunkan bakteri Coli-form pada air payau dapat menggunakan saringan pasir dan arang kayu dengan waktu kontak selama $\geq 1$ jam.

\section{Penurunan bakteri Coli-fecal}

Dari tabel 4.2 diatas terlihat bahwa rata-rata MPN bakteri coli-fecal sebelum melalui saringan pasir dan arang kayu dan kontrol sebanyak 265, penurunan rata-rata MPN bakteri Coli-fecal sesudah melalui saringan pasir dan arang kayu waktu kontak 1 jam sebanyak MPN = 10 (96,2 \%), waktu kontak 2 jam sebanyak MPN $=6(97,7 \%)$ dan waktu kontak 3 jam sebanyak MPN = 5 (98,1\%).Melihat hasil penelitian diatas terdapat perbedaan prosentase penurunan yang signifikan, yaitu semakin lama waktu kontak air payau dalam media saringan pasir dan arang kayu, semakin besar prosentase penurunan MPN bakteri Coli-fecal dalam air payau.

Hasil uji t-tes dependent pada tabel 4.6 penurunan MPN bakteri Coli-fecal mulai dari waktu kontak air payau selama 1 jam, 2 jam dan 3 jam dalam saringan pasir dan arang kayu terlihat hasilnya $\mathrm{p}_{\text {value }}=0,001(\mathrm{p}<\alpha=0,05)$, berarti ada pengaruh waktu kontak air payau selama 1 jam, 2 jam dan 3 jam dalam saringan pasir dan arang kayu terhadap penurunan bakteri Coli-fecal. Hal ini sesuai dengan hasil penelitian Herman,Hermawan,2006 bahwa ada pengaruh ketebalan saringan pasir lambat model IOS$\mathrm{SF}$ terhadap penurunan total Coli-tinja $(\mathrm{p}$ value $=0,001<\alpha$ $=0,05)$.

Secara keseluruhan penyisihan kontaminan dengan proses filtrasi merupakan kombinasi dari beberapa proses yang berbeda - beda, dan yang terpenting adalah mechanical straining, sedimentasi, dan adsorpsi, dan aktivitas biologi (Huisman, 1974 dalam Safira Astari dan Rofiq Iqbal).

Dengan demikian dapat disimpulkan bahwa saringan pasir dan arang kayu efektif dapat digunakan untuk menurunkan bakteri Coli-fecal dalam air payau dengan waktu kontak 1 jam ( rata-rata $M P N=10$ ) telah memenuhi standar syarat air bersih bukan untuk perpipaan MPN Total Coliform $=50 / 100 \mathrm{ml}$ sampel (Permenkes Nomor 416/1990).

\section{Penurunan Kekeruhan}

Hasil penelitian pada tabel 4.3 terlihat bahwa konsentrasi kekeruhan air payau sebelum penyaringan dan kontrol ratarata 36,025 NTU, setelah melalui saringan pasir dan arang kayu dengan waktu kontak 1 jam rata-rata kekeruhan 4,41 
NTU (87,7\%) , waktu kontak 2 jam rata-rata kekeruhan menjadi 4,2 NTU (88,3\%) dan waktu kontak 3 jam ratarata menjadi 5,20 NTU (85,6\%). Berdasarkan Permenkes Nomor 416/ 1990 persyaratan kualitas air minum, kadar maksimum kekeruhan yang diperbolehkan adalah 5 NTU. Jadi dari hasil penelitian diatas dapat dilihat bahwa dengan waktu kontak air payau selama 1 jam dan 2 jam dalam saringan pasir dan arang kayu telah dapat memenuhi persyaratan air minum dengan kadar kekeruhan $<5$ NTU.

Hasil uji t-tes independen pada tabel 4.7 dapat dilihat sesudah perlakuan dengan waktu kontak 1 jam, air payau dalam saringan pasir dan arang kayu mempunyai rata-rata kekeruhan $=4,4$ NTU dengan $\mathrm{p}_{\text {value }}: 0,001(\mathrm{p}<\alpha=0,05)$. Pada waktu kontak selama 2 jam mempunyai rata-rata kekeruhan $=4,2 N T U$ dengan $\mathrm{p}_{\text {value }}: 0,001(\mathrm{p}<\alpha=0,05)$. Pada waktu kontak selama 3 jam mempunyai rata-rata kekeruhan $=5,2 N T U$ dengan $\mathrm{p}_{\text {value }}: 0,001(\mathrm{p}<\alpha=0,05)$. Ini berarti bahwa ada pengaruh waktu kontak air payau selama mulai 1 jam, 2 jam dan 3 jam dalam saringan pasir dan arang kayu terhadap penurunan kekeruhan.

Dengan demikian dapat disimpulkan bahwa saringan pasir dan arang kayu efektif dapat digunakan untuk menurunkan kekeruhan dalam air payau dengan waktu kontak 1 jam.

\section{Penurunan Salinitas.}

Hasil penelitian pada tabel 4.4 terlihat bahwa penurunan salinitas air payau sebelum penyaringan dan kontrol ratarata 3,5 mg/l, setelah melalui saringan pasir dan arang waktu kontak 1 jam rata-rata salinitas : 2,0 mg/l penurunan (42,8 \%), pada waktu kontak 2 jam rata-rata salinitas : 1,3 mg/l penurunan ( 62,8 \%) dan pada waktu kontak 3 jam rata-rata salinitas menjadi : 0,5 mg/l penurunan (85,7\%).

Berdasarkan hasil penelitian ini, bahwa penurunan salinitas air payau dalam saringan pasir dan arang kayu memerlukan waktu kontak semakin lama semakin menurun tertinggi pada waktu kontak 3 jam sebesar 85,7 $\%$.

Hasil uji t-test independet pada tabel 4.7 dapat dilihat sesudah perlakuan dengan waktu kontak 1 jam air payau dalam saringan pasir dan arang kayu mempunyai rata-rata salinitas = 2,0 mg/l dengan CI-95 \% (1,2516 - 1,7484 ) nilai $\mathrm{p}_{\text {value }}=0,001$ atau $(\mathrm{p}<\alpha=0,05)$. Pada waktu kontak selama 2 jam mempunyai rata-rata salinitas $=1,3 \mathrm{mg} / \mathrm{l}$ dengan $95 \%$ - CI ( 1,7032 - 2,6968 ) nilai $\mathrm{p}$ value $=0,001$ atau ( $\mathrm{p}<\alpha=0,05)$. Pada waktu kontak selama 3 jam mempunyai rata-rata salinitas $=0,5$ dengan $95 \%$ - CI ( $2,7516-3,2484)$ nilai $\mathrm{p}_{\text {value }}=0,001$ atau $(\mathrm{p}<\alpha=0,05)$.

Melihat hasil uji t-test independent ada pengaruh yang signifikan waktu kontak air payau dalam saringan pasir dan arang kayu terhadap penurunan salinitas, dan menurut Permenkes Nomor : 492/Menkes/Per/IV/2010 tentang persyaratan kualitas air minum konsentrasi salinitas $=2,5$ gr/l. Jadi hasil penelitian dinyatakan telah memenuhi syarat.

Menurut teori, karakteritik arang kayu berwarna hitam, tidak berbau, tidak berasa, dan mempunyai daya serap yang jauh lebih besar dibandingkan dengan karbon yang belum menjalani proses aktivasi, serta mempunyai permukaan yang luas, yaitu antara 300-2000 m/gram. Luas permukaan yang luas disebabkan karbon mempunyai permukaan dalam (internal surface) yang berongga, sehingga mempunyai kemampuan menyerap gas dan uap atau zat yang berada didalam suatu larutan.

Arang kayu menurut bentuknya dapat dibagi menjadi 2 kelompok, yaitu bentuk bubuk dan granular. Karbon bentuk bubuk digunakan untuk absorbsi dalam larutan, misalnya untuk menghilangkan warna (declorisasi), sedangkan karbon bentuk granular digunakan untuk absorbsi gas dan uap, dikenal pula sebagai karbon pengadsorbsi gas. Karbon bentuk granular kadang-kadang juga digunakan di dalam media larutan khususnya untuk deklorinasi air dan untuk penghilang warna didalam larutan serta pemisahan komponen-komponen dalam suatu sistem yang mengalir (Meilita, T, 2007).

Pada penelitian ini arang kayu yang dipakai adalah arang kayu bakau belum diaktivasi dan memiliki berdiameter 1-2 cm. Kemungkinan karena arang kayu bakau yang dipakai dibeli dari toko, jadi belum diaktivasi dan tidak berbentuk granul; sehingga daya adsorbsi salinitas dalam air payau belum maksimal. Untuk itu perlu penelitian lanjutan terhadap saringan pasir dan arang kayu , dengan mengunakan arang kayu yang sudah diaktivasi dalam bentuk granul.

\section{Uji beda penurunan MPN Coli-form}

Pada tabel 4.8 uji beda waktu kontak pada Pre-tes dengan 1 jam memiliki beda nyata penurunan MPN Coliform dengan nilai $\mathrm{p}_{\text {value }}=0,001<\alpha=0,05$, pada $95 \%$-CI ( 164,9764 - 245,6902), dengan waktu kontak 2 jam memiliki beda nyata dengan nilai $\mathrm{p}_{\text {value }}=0,001<\alpha=0,05$, pada 95\%-CI ( 206,3098 - 287,0236), serta dengan waktu kontak 3 jam memiliki beda nyata dengan nilai $\mathrm{p}_{\text {value }}=$ $0,001<\alpha=0,05$, pada 95\%-CI (213,6431 - 294,3569).

Perbedaan waktu kontak pada 1 jam dengan Pre-tes memiliki beda nyata dengan nilai $\mathrm{p}_{\text {value }}=0,001<\alpha=0,05$, pada 95\% - CI ( -245,6902 - ( - 164,9764), waktu kontak 1 jam dengan 2 jam memiliki beda nyata dengan nilai $\mathrm{p}_{\text {value }}=0,046<\alpha=0,05$, pada $95 \%$ - CI $\quad(0,9704-$ 81,6902), waktu kontak 1 jam dengan 3 jam memiliki beda nyata dengan nilai $\mathrm{p}_{\text {value }}=0,024<\alpha=0,05$, pada $95 \%$ - CI (8,3098-89,0236).

Terlihat pada waktu kontak 1 jam memiliki beda nyata terhadap penurunan MPN Coli-form dengan waktu kontak pada 2 jam dan 3 jam. Ini berarti bahwa dengan waktu kontak air payau selama 2 jam dalam media saringan pasir dan arang kayu telah dapat menurunkan MPN Coli-form dari sebesar 57 menjadi 18,3 (penurunan MPN Coli-form mencapai 91,1 \%). Hasil ini dinyatakan telah memenuhi syarat kualitas bakteriologis untuk air bersih (Permenkes No.416/1990, MPN Coli-form maksimum yang diperbolehkan untuk air bukan perpipaan $=50 / 100 \mathrm{ml}$ sampel).

\section{Uji beda penurunan Kekeruhan.}

Pada tabel 4.10 uji beda terlihat perbedaan waktu kontak pada pre-tes

dengan 1 jam memiliki beda nyata penurunan Kekeruhan dengan nilai $\mathrm{p}_{\text {value }}=0,001<\alpha=0,05$, pada $95 \%$-CI ( 
31,2607 - 31,9693), dengan waktu 2 jam memiliki beda nyata dengan nilai $\mathrm{p}_{\text {value }}=0,001<\alpha=0,05$, pada $95 \%$ - CI (31,3840 - 32,0926), serta dengan 3 jam memiliki beda nyata dengan nilai $\mathrm{p}_{\text {value }}=0,001<\alpha=0,05$, pada $95 \%$-CI $(30,4740$ - 31,1826).

Perbedaan waktu kontak pada 1 jam dengan pre-tes memiliki beda nyata dengan nilai $\mathrm{p}_{\text {value }}=0,001<\alpha=0,05$, pada $95 \%$ - CI ( $-31,9693-(-31,2607)$, dengan waktu kontak 2 jam tidak memiliki beda nyata dengan nilai $\mathrm{p}_{\text {value }}$ $=0,445>\alpha=0,05$, pada $95 \%$ - CI $\quad(-0,2310-0,4776)$, serta dengan 3 jam memiliki beda nyata dengan nilai $\mathrm{p}_{\text {value }}$ $=0,001<\alpha=0,05$, pada 95\% - CI $(-1,1410-(-0,4324)$.

Ini berarti bahwa waktu kontak air payau dalam media saringan pasir dan arang kayu pada perlakuan 1 jam dengan 2 jam terhadap penurunan kekeruhan tidak berbeda nyata, jadi dapat disimpulkan bahwa dengan waktu kontak 1 jam air payau sudah dapat menghasilkan kekeruhan air bersih yang dihasilkan telah memenuhi syarat sesuai dengan Permenkes No.416/1990 bahwa kekeruhan kadar maksimum yang diperbolehkan 5 NTU.

\section{Uji beda penurunan Salinitas.}

Pada tabel 4.12 uji beda waktu kontak air payau dalam media saringan pasir dan arang kayu pada pre-tes dengan 1 jam memiliki beda nyata penurunan Salinitas dengan nilai $p_{\text {value }}=0,001<\alpha=0,05$, pada $95 \%$-CI ( $\left.1,2694-1,7306\right)$, dengan 2 jam memiliki beda nyata dengan nilai $\mathrm{p}_{\text {value }}=$ $0,001<\alpha=0,05$, pada 95\%-CI ( 1,9694 - 2,4306), serta dengan 3 jam memiliki beda nyata dengan nilai $\mathrm{p}_{\text {value }}=$ $0,001<\alpha=0,05$, pada $95 \%$-CI $(2,7694-3,2306)$.

Demikian juga perbedaan waktu kontak pada 1 jam dengan Pre-tes memiliki beda nyata dengan nilai $\mathrm{p}_{\text {value }}$ $=0,001<\alpha=0,05$, pada $95 \%$ - CI $\quad(-1,7306-(-1,2694)$, dengan 2 jam memiliki beda nyata dengan nilai $\mathrm{p}_{\text {value }}$ $=0,001<\alpha=0,05$, pada $95 \%$ - CI $\quad(0,4694-0,9306)$, serta dengan 3 jam memiliki beda nyata dengan nilai $\mathrm{p}_{\text {value }}$ $=0,001<\alpha=0,05$, pada $95 \%$ - CI $(1,2694-1,7306)$.

Ini berarti bahwa waktu kontak 3 jam lebih baik penurunan salinitas air payau hasil saringan pasir dan arang kayu dibandingkan dengan waktu kontak 2 jam, dan 1 jam. Dengan kata lain untuk menurunkan salinitas air payau dengan media saringan pasir dan arang kayu memerlukan waktu kontak minimal 1 jam dengan penurunan dari pretes sebesar 3,5 gr/l menjadi 2,0 gr/l dan sudah sesuai dengan persyaratan air bersih (Permenkes Nomor 416/1990).

\section{Kesimpulan dan Saran}

\section{Kesimpulan}

1. Saringan pasir dan arang kayu dapat menurunkan MPN Coli-form 95,8 \%, kekeruhan 85,6 \% dan salinitas 85,7 \% dengan waktu kontak 3 jam.

2. Ada pengaruh waktu kontak air payau dalam saringan pasir dan arang kayu selama $1 \mathrm{j}$ am, 2 jam dan 3 jam (p value $<\alpha=0,05)$ terhadap penurun MPN Coli-form dan Coli-fecal.

3. Ada pengaruh waktu kontak air payau dalam saringan pasir dan arang kayu selama 1 jam, 2 jam dan 3 jam ( $\mathrm{P}$ value $<$ $\alpha=0,05)$ terhadap penurun kadar Kekeruhan.
4. Ada pengaruh waktu kontak air payau dalam saringan pasir dan arang kayu selama 1 jam, 2 jam dan 3 jam (p value $<\alpha=0,05)$ terhadap penurunan salinitas.

\section{Saran}

1. Masyarakat Pulau Sicanang pemakai air payau dapat menggunakan saringan pasir dan arang kayu untuk menurunkan bakteri Coli form, Coli-fecal, Kekeruhan dan Salinitas dengan waktu kontak 1 jam.

2. Petugas Puskesmas Medan Labuhan dapat mensosialisaikan pemanfaatan saringan pasir dan arang kayu untuk memperoleh air bersih yang memenuhi syarat bagi masyarakat di daerah yang memanfaatkan air payau.

3. Perlu penelitian lanjutan penggunaan saringan pasir dan arang kayu dengan satu tabung, waktu kontak < 1 jam dan menggunakan arang batok kelapa bentuk granul yang telah diaktivasi dengan menambah parameter lain misalnya : Total Suspended Solid (TSS), $\mathrm{pH}, \mathrm{Fe}, \mathrm{Mn}$ terhadap air sumur gali / air sungai / air gambut.

\section{Daftar Pustaka}

Aimyaya,2013;Saringan pasir arang, http://nanosmartfilter.com, diakses tgl.17 Nop. 2013.

Badan Pengkajian dan Penerapan Teknologi, 1999; Kesehatan Masyarakat dan Teknologi Peningkatan Kualitas air, Direktorat Teknologi Lingkungan Deputi Bidang Teknologi Informasi,Energi, Material dan Lingkungan, Jakarta.

Depkes RI,2010;Keputusan Menteri Kesehatan RI No :492/Menkes/Per/IV/2010 Tentang Persyaratan Kualitas Air Minum, Jakarta. ,1992;Petunjuk pelaksanaan dalam pengumpulan data Bakteriologis Usap Alat Makan/Masak, Usap Dubur Penjamah, Contoh Makanan Jadi dan Contoh Air, Jakarta.

-1991; Pedoman bidang studi pengawasan pencemaran lingkungan fisik pada institusi Pendidikan Tenaga Kesehatan Lingkungan, Jakarta.

-;2010;Permenkes

RI

No:492/Menkes/SK/IV/2010 Tentang

Persyaratan air minum, Jakarta.

;1990; Permenkes RI No: 416/Menkes/SK/XI/1990 Tentang Syaratsyarat dan pengawasan kualitas air bersih, Jakarta.

Hannafiah Kemas Ali, 2003; Rancangan Percobaan Teori \& Aplikasi, cetakan 8, PT.Raja Grafindo Persada, Jakarta.

Herman, Hermawan; 2006; Pengaruh ketebalan saringan pasir lambat model IOS-SF terhadap penurunan Total Coli-form dan Coli-tinja sebagai dampak penurunan 
kekeruhan pada air kolam sebagai air bersih, Thesis, Undip, Semarang.

Huisman (1974); Slow Sand Filter , University of Technology, Netherlands.

Indo Tecno plus, Manual Book I Water Test Kit AYI-10 Sanitarian Field Kit for Water Quality, Inscien Pro.

Kusnaedi, 2006; Mengolah air gambut dan Air Kotor untuk minum, Penebar, Swadaya, Jakarta.

1998; Pengolahan air, Bagian Peneribitan PT.Gramedia Pustaka Utama, Jakarta.

Meilita, T, 2007; Arang Aktif (Pengenalan dan proses pembuatannya), http://library.usu.ac.id/Arang Aktif, diakses tanggal 8 Nopember 2013.

Nusa, Idaman Said, 1999; Kesehatan Masyarakat dan Teknologi Kualitas Air , Peneribit Direktorat Teknologi Lingkungan,Deputi Bidang TIEML,BPPT, Jakarta.
Safira Astari, Rofiq Iqbal; Realibility of Slow Sand Filter for Water Treatment; Prodi Teknik Lingkungan Fakultas Teknik Sipil dan Lingkungan ITB-Bandung.

Satrio, Wibowo, Teknik Penjernihan Air, http://aimyaya.com/id, diakses tanggal 8 Nopember 2013.

Sugandi,E.Sugiarto,1994; Rancangan Percobaan Teori dan Analisis, Andi Offset, Yogyakarta.

Sumarno, 2000; Isolasi dan Identifikasi Bakteri Klinik, AAK Yogyakarta. 